\title{
Pharmacology of active principles of vegetable origin included in tinctures
}

\author{
Valentin Nănescu ${ }^{1}$, Daniela Cîrţînă ${ }^{1}$ \\ 1“Constantin Brâncusi” University of Targu-Jiu, Faculty of Medical and Behavioral Sciences, \\ No. 4, Tineretului St., Tg-Jiu, Romania \\ E-mail: danielacirtina@gmail.com
}

\begin{abstract}
This paper highlights the importance of using tinctures and this is only due to a quick and easy assimilation in the body and the pharmacology of the active principles found in plants that are responsible for the action or actions that the tincture will have. The preparation of tinctures is also an essential step, because it is important to be able to benefit to the maximum from these active principles and one month or one year after the preparation of the tincture.
\end{abstract}

Keywords: active principles, tincture, action, effects

\section{Introduction}

Pharmacology is the science that deals with the study of drugs in relation to living organisms and systems, and phytotherapy refers to a therapy that is performed with the help of the cell plant that biosynthesizes the active substances. The notion of phytotherapy started from medicinal teas and extended to everything that means pharmaceutical or medicinal product in the formula of which will enter as such the medicinal plant along with pure active and extractive substances that are obtained from the plant kingdom. There is also a mixed pharmaceutical product in which formula will be found, along with some active substances from plants, and compounds of semisynthesis and synthesis. Medicinal plants in the form of infusions, teas, syrups, decoctions, tablets, ointments, creams, capsules, tinctures are used for therapeutic purposes. Tinctures are phytotherapeutic forms for internal use, they being hydroalcoholic extractive solutions, are those pharmaceutical forms in which the plants will be percolated or macerated in a mixture made from a higher concentration of alcohol and a lower of water. Both percolation and maceration are two methods of cold extraction of active ingredients.

One of the processes that lead to the production of tinctures is represented by maceration which is the process by which therapeutic substances are extracted from chopped plants, it is also a process that can be easily done at home. It can last for 8 or 10 days, with a food alcohol concentration of $45^{\circ} \mathrm{C}$, $60^{\circ} \mathrm{C}$ and $70^{\circ} \mathrm{C}$. The three essential elements of the maceration process are the alcohol concentration, the amount of plant to be extracted and the extraction time. For a good extraction, the preparation must be shaken at least three times a day and stored in tightly closed bottles. Another method is that of percolation, which can be multiple or simple, representing, moreover, a faster method of making tinctures. It is made with the help of the percolator (Fig. 1) which is the extraction device and have the form of a conical trunk cylinder with tap, being made of stainless material, enameled iron or glass, who allows the circulation of alcohol from top to bottom, obtaining in this way drop by drop. A final process for making tinctures would be vibroextraction or turboextraction, which is the fastest process for making tinctures, being performed using special equipment on an industrial scale. 


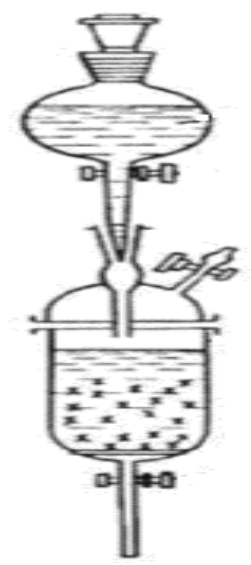

Figure 1 Percolator

The advantages of tinctures are represented by their long shelf life, their simple administration in the form of drops, the fact that their recommendation is aimed at anyone, especially people with hypertension or edema and who are not allowed to consumes a lot of liquids and the fact that the extraction will be complete due to the hydro-alcoholic environment, which only helps the plant product to act completely gently, but also with force, an antagonism found only in natural products. Another great advantage of tinctures, compared to a dragee that can only contain an active ingredient of a certain plant substance, is the effect it has that cannot be compared.

Tinctures contain the active principles of a plant, extracting from the plant principles that are soluble in water and alcohol, and in order to get the most out of these active principles of the plant, it must be harvested at a certain time, the tinctures are obtained from mature plants. The active principles or active substances are those responsible for the therapeutic effect, they are defined as chemically pure medicinal substances that have a pharmacodynamic effect and can be classified according to their physicochemical properties, chemical structures and biological effects (Table 1) [3].

Although a tincture can be obtained at home in a very easy way, it cannot be compared with a tincture obtained in a specialized laboratory because it must be considered what part of the plant must be used, at what temperature the extraction will be performed in order to obtain the maximum of the active principles in the plant, which is the concentration of alcohol used to obtain a maximum effect and how this will be concentrate or dilute in order to maintain the same effectiveness in a few months or years.

Sea buckthorn tincture contains active substances such as essential oils, vitamin B1, B2, B3, B12 and $\mathrm{C}$, thus having antianemic, stomachic, general tonic, antirheumatic, antiseptic properties in the urinary tract, vitaminizing being used in avitaminosis, asthenia, dermal infections, gastrointestinal infections, urticaria, allergic conditions, neuroendocrine diseases, circulatory diseases, liver diseases and in the treatment of weight problems, anorexia, viral hepatitis, growth disorders and diseases of the spinal cord thus helping to restore the body after disease, increase general resistance, strengthening the immune system, vitaminizing the body, protecting cells, protecting tissues and liver cells against oxidative stress. Sea buckthorn tincture is contraindicated in pregnancy and lactation, in children under 12 years, in people allergic to sea buckthorn and people who have been banned from alcohol. It will be administered internally on an empty stomach, 3 or 4 times a day, by diluting a quantity of $5 \mathrm{ml}$ of tincture in $50 \mathrm{ml}$ of tea or water.

Thyme tincture contains as active ingredients tannins, volatile oil, rosemary acid, caffeic acid, bitter substances it is a good antiseptic, antifungal, antitussive, digestive, choleretic, respiratory stimulant, dewormer and nerve tonic, it manages to maintain health, lar of the bronchi and trachea, to 
reduce the risk of bacterial contamination of the digestive and respiratory tract, to reduce the condition of bloating, to increase appetite, to intervene strongly on the kidneys and intestines, helping their functioning in normal parameters.

Table 1. Classification of active principles

\begin{tabular}{|c|c|c|}
\hline Active principles & Characteristics & Examples \\
\hline Alkaloids & $\begin{array}{l}\text { - Nitrogen-containing organic } \\
\text { compounds; } \\
\text { - It has a strong } \\
\text { pharmacodynamic effect; } \\
\text { - It has water-soluble salts; } \\
\text { - Has alkaline reactions. }\end{array}$ & $\begin{array}{l}\text { - Atropine found in Atropa Belladonna, } \\
\text { Datura stramonium; } \\
\text { - Codeine, morphine, papaverine present } \\
\text { in poppy seeds; } \\
\text { - Capsaicin present in the hot artery; } \\
\text { - Colchicine found in toad root; } \\
\text { - Ergotamine, ergotoxin, ergometrine from } \\
\text { rye horn; } \\
\text { - Pilocarpine which is extracted from the } \\
\text { leaves of Pilocarpus microphylus and } \\
\text { jaborandi; } \\
\text { - Ephedrine from Ephedra. }\end{array}$ \\
\hline $\begin{array}{l}\text { Essential oils } \\
\text { (Volatile) }\end{array}$ & $\begin{array}{l}\text { - Volatile, fat-soluble } \\
\text { compounds; } \\
\text { - It has an aromatic smell; } \\
\text { - It has spasmolytic and } \\
\text { antiseptic action. }\end{array}$ & $\begin{array}{l}\text { - Thyme oil; } \\
\text { - Peppermint oil; } \\
\text { - Eucalyptus oil; }\end{array}$ \\
\hline Saponins & $\begin{array}{l}\text { - It has a glycosidic structure; } \\
\text { - It has properties: } \\
\text { - Emulsifiers; } \\
\text { - Surfactants; } \\
\text { - They have an irritating } \\
\text { effect at the local level; } \\
\text {-I produce hemolysis by } \\
\text { intravascular injection. }\end{array}$ & $\begin{array}{l}\text { - Infusion with Primula root that has an } \\
\text { expectorant effect; } \\
\text { - They are also found in Hederae leaves; } \\
\text { Calendulae flowers, in the bark of the } \\
\text { Mimosa tenuiflora tree having a healing } \\
\text { and cyclotrophic effect, due to the } \\
\text { increase of collagen synthesis; } \\
\text { - In licorice root with antiulcer action; } \\
\text {-In chestnut seeds, having vasoprotective } \\
\text { action. }\end{array}$ \\
\hline Glycosides & $\begin{array}{l}\text { It has two components: } \\
-\quad \text { the carbohydrate part } \\
\text { containing several oases; } \\
\text { - the non-carbohydrate part } \\
\text { which is responsible for the } \\
\text { pharmacodynamic effect. }\end{array}$ & $\begin{array}{l}\text { - Cardiotonic glycosides found mainly in } \\
\text { the leaves of some plants that are part of } \\
\text { the Scrophulariaceae family and the } \\
\text { Apocynaceae family; } \\
\text { - Anthracenosides found in the roots, bark } \\
\text { and leaves of Rhamnus frangula. }\end{array}$ \\
\hline $\begin{array}{l}\text { Substances } \\
\text { mucilaginous }\end{array}$ & $\begin{array}{l}\text { - Compounds having a } \\
\text { polysaccharide structure; } \\
\text { - Forms viscous colloidal } \\
\text { solutions together with water; } \\
\text { - Make a protective film on } \\
\text { the surface of the mucosa. }\end{array}$ & - Mallow infusion \\
\hline Tanning substances & $\begin{array}{l}\text { - It has a chemical structure } \\
\text { of condensed polyphenolic } \\
\text { derivatives; } \\
\text { - It has an astringent action. }\end{array}$ & -They are found in blueberry fruits. \\
\hline
\end{tabular}


Artichoke tincture, made from artichoke leaves, is a preparation recommended in angina pectoris, liver failure, cirrhosis, chronic hepatitis, chronic nephritis, atherosclerosis, obesity, enteritis, biliary dyskinesia, hemorrhoids, overwork, intoxication, rheumatism, asthenia acts as a diuretic, choleretic, hepatic antitoxic, antipyretic, hypocholesterolemic, antirheumatic, tonic-bitter, it manages to contribute very well to everything that means an increase in intestinal transit, a maintenance of blood fats and cholesterol in normal concentrations and maintaining the health of the liver by protecting liver cells, stimulating the production and elimination of bile and detoxifying the liver [4]. All these uses are due to the complex therapeutic action that is imprinted by the phytocomplex by the presence of chlorogenic acid, cynarin, cinnaropricrine, cinnaroside, flavones and polyphenolic derivatives.

Echinacea tincture contains cinnarine, chicory acid, pollen derivatives, polyholosides, pyrrolizidine alkaloids, volatile oil with a significant amount of esters, alkamines. It has antibacterial and antiviral effects due to caffeic acid esters, anti-inflammatory due to polyholosides and alkanolamines, healing, immunostimulatory due to alkamines, polyholosides and caffeic acid esters that will stimulate the activity of cells that provide non-specific protection of the body the penetration into the body of pathogens inhibiting hyaluronidase, being recommended in urinary tract infections and in chronic and acute infections of bacterial or viral origin of the respiratory tract. It is administered on an empty stomach, 3 or 4 times a day, $5 \mathrm{ml}$ of tincture which is diluted in $50 \mathrm{ml}$ of tea or water [5, 6]. It also has some contraindications for patients who have undergone organ transplantation, autoimmune diseases, tuberculosis, multiple sclerosis, collagenosis, leukosis, diabetes, AIDS, in individuals with allergies to echinacea, pregnancy and lactation, children under 12 years, individuals who were not banned from drinking alcohol.

Angelica tincture is indicated in skin diseases such as psoriasis, acne, dermatoses of unknown etiologies, scleroderma, in frequent indigestion, digestive atony, dyspepsia, bulimia, appetite disorders, anorexia, seborrheic skin problems to help it maintaining skin tone and youth, in convalescence, nervous and physical exhaustion, excessive sensitivity to climatic factors, mental confusion, psychosis, neurosis, depression, hysteria administered 3-4 times a day, on an empty stomach, $5 \mathrm{ml}$ of tincture diluted in $50 \mathrm{ml}$ of water [7,8 ]. All these actions and effects are due to the chemical composition containing simple coumarins and furanocoumarins, volatile oil rich in monoterpenic hydrocarbons, flavonic derivatives, sterols, oases, caffeic acid and chlorogenic acid and resins.

Chestnut tincture contains as active ingredients coumarin derivatives, tannins, triterpene saponins and purines with astringent, antiedematous, venotonic, capillary-protective and anti-inflammatory action, leading to its use in chronic venous insufficiency, post-traumatic edema, edema of the lower limbs, thrombophilia, varicose veins, hemorrhoids, muscle pain and cramps, rheumatic joint pain and inflammation by its internal administration in the form of drops, 15 drops diluted in $50 \mathrm{ml}$ of water, 3 times a day or externally diluting $5 \mathrm{ml}$ of tincture in $50 \mathrm{ml}$ of boiled water and then cooled and applied to the affected area in the form of compresses [9].

\section{Conclusions}

To maintain the health of the body, tinctures can be a real godsend, because depending on the plant from which the extraction will be performed, the tinctures can have a wide range of recommendations. They can be easily prepared, can be prepared at home and can be used to treat pain, stress, colds, coughs, to cure skin conditions, contusions, wounds. They can be extremely useful due to the rapid action they have, they are quickly and easily assimilated by the body, the tincture is actually the sap of the plant. It can be a cure for both the psyche and the body, but it can also be used as a preventive measure, managing to block the onset of disease through its prophylactic action. Calming, digestive tinctures or tinctures can be used to eliminate stress, maintain immunity or increase it, depending on the predisposition to a particular disease of each individual. 


\section{References}

[1] Cristea A.N., General pharmacology, Editura Medicala, Bucuresti, 2006.

[2] Duță V., Treatment of diseases through diet, Editura Libris, București, 2006.

[3] Foret R., The alchemy of nature, Editura Paralela 45, București, 2019.

[4] Natea C. N., Nutrition and dietetics, Editura Universității "Lucian Blaga", Sibiu, 2008.

[5] Nica-Badea D., Control of active ingredients in exciting foods, Editura Academica Brâncuși, 2011.

[6] Popescu O., Bojor O. Traditional and modern phytotherapy, Ed. a II-a, Editura Fiat Lux, București, 2001

[7] Vasey C., Translation Alexandra Născuțiu- Detoxification Guide - Simple methods to eliminate toxins from the body, Editura Niculescu, București, 2008

[8] https://www.ncbi.nlm.nih.gov/pmc/articles/PMC3634921/

[9] https://www.who.int/traditional-complementary-integrative-medicine 